\title{
A study on the Tendency of Localization for Game Environment Design \\ - Based on the Analysis in Romance of the Three Kingdoms
}

\author{
Meng Wei, Dong-Min Cho \\ Dept. of Industrial Design, Chonbuk National University
}

게임배경디자인의 한.중.일 지역적 특성에 관한 연구 - 삼국지게임 대상으로

\author{
멍웨이, 조동민 \\ 전북대학교 예술대학 산업디자인학과 \\ mellgipson@daum.net
}

\begin{abstract}
With the development of chinese online games rapidly, Game markets need the actual possibilities of practical game's technology increasingly. Additionally Lack of originality of the Chinese online games couldn't be appropriated for consumer's preferences, so it is necessary that the talents in a game design and management should be cultivated. When we cultivate the talents, we should pay attention to the various styles in different countries, that is why we will make a comparative study on the games respectively achieved in China, Japan, and Korea according to the romance of the three kingdoms. They respected the traditional Chinese cultures as materials of this theme, it is worth learning and referencing. We had selected representative 6 games among 25 three Kingdom games and 2 games for each country as a stimulus of the game architectural design in the backgrounds design, with using of SPSS regression analysis, Therefore, this research will provide the references for the better development talents of whom can not only understand Chinese traditional culture but also adapt to the needs of game development.
\end{abstract}

Keywords : Game environment design(게임배경디자인), Culture(문화), Romance of the Three Kingdoms(삼국지), localization(지역성)

\section{요 약}

게임개발환경의 빠른 성장에 맞춰 게임시장은 더욱 실질적인 게임기술을 필요로 하지만 중국 온라인 게임은 같은 장르의 대부분 게임 스타일이 비슷하며 게임유저 선호에 밀접한 독창성에 대한 부분은 미흡하다. 따라서 전 세계에 거친 유저들이 동시에 이용하는 온라인 게임의 경우 각 나라만의 게임그래픽 선호도의 지침이 중요한 사항인데 반해 제작국가의 불분명성에 기인한 디자인이 만연하다. 한국, 중국, 일본은 이미 유명한 스토리텔링의 주제인 “삼국지”를 기반으로 중국의 전통문화와 자기나라의 상황을 결합하여 게임 디자인을 진행하였다. 각 나라의 독특한 게임디자인 스타일은 분명히 존재하며 산업적 활용성 차원의 게임디자인에 도움이 되는 연구가 치로써 중요한 배경을 이룬다. 본 연구는 각 나라의 25개의 “삼국지 게임"을 주제로 한 온라인 게임을 연구대상으로 게임 배경 디자인 요소를 회귀분석을 통한 비교분석을 진행하여 각 나라 의 디자인 특징을 설명, 향후 동종연구자들 및 실질적인 게임그래픽 디자이너의 게임디자인 개 발에 효율적인 방향을 제언하려 한다.

Received: Jul. 22, 2013 Revised: Aug. 12, 2013

Accepted: Aug. 23, 2013

Corresponding Author: Dong-Min Cho(Chonbuk National University)

E-mail: mellgipson@daum.net

ISSN: 1598-4540 / elSSN: 2287-8211
(C) The Korea Game Society. All rights reserved. This is an open-access article distributed under the terms of the Creative Commons Attribution Non-Commercial License (http://creativecommons.otg/licenses/by-nc/3.0), which permits unrestricted non-commercial use, distribution, and reproduction in any medium, provided the original work is properly cited. 
- A study on the Tendency of Localization for Game Environment Design

- Based on the Analysis in Romance of the Three Kingdoms -

\section{Introduction}

The online games industry is a newly arisen culture contents industry that relies on modern information technique, especially hard-software technique of the computer and network communication technique. Because of its products not only concentrate the essence of traditional games, but also gathers the vogue, interact, contest, imitation and other entertainment factors all in one, they can meet the entertainment experiences needs of people more completely. With the increase of efficiency and the development of internetwork, the online games industry plays more and more important roles in the economy and cultural life. It has been more than ten years since online games emerged in our country. The speed of development was prodigious. Online game has become a mainstay of current culture industry and it has brought about many effects on our society. There are hundreds of types of online games are operated in China. More and more the operation of online games and the number of game player are constantly increasing. The power of influence of game products and game industry on our society is getting larger. However, It is a pity that the overwhelming majority of games in our country which have been introduced from abroad; even a lots of works have been imitated foreign products.

\section{Empirical Study}

The Three Kingdoms ${ }^{1)}$ is one of the theme which are used frequently. In the past ten years, This theme on "the Three Kingdoms" has been still unfailing in the game market for its great cultural deposits.

\subsection{Preference analysis of Three countries}

\subsubsection{Korea}

Korean aesthetic factors are good at performing. Korean game design style has a diversity[1]. From the colors, Korean game character's clothing and color feeling are more vivid and colorful than China and Japan's. For example, It has almost red, orange, yellow, green, blue as primary colors. also korean styles advocate individualism, they use colorful fashioned clothes to the highlight of their personality, emphasis on self-advocate and pursuit that nature and life combined, Korean art values are the closest to a nature so characters of game always co-exist with the nature[2].

\subsubsection{China}

Chinese game design is neither beautiful nor simple, just abundant. Chinese red means good omen and wealth[3]. Because of the osmosis of a nature, Chinese styles advocate more artificial traces on a garden art, moreover, it maybe influenced by Taoism for a long time, Chinese make a scene atmosphere a kind of a misty air of inspiration. Chinese people like a peony which is from the ancient times for a symbol of wealth and good fortune. Peony petals are large, sumptuous which means their

1) The Three Kingdoms : a Chinese historic period after the Easter Han of Dynasty, Wei, Shu, Wu Empire divide China into three parts and they rule each of them. It is from 220B.C. to 280B.C, 61 years in total. 
favorite features are big power and beautiful huge aesthetics and it also similar to Chinese people's temperament[2].

\subsubsection{Japan}

Japanese aesthetic factors are stable, make people feel "silent." As for the colors, Japanese avoid bright colors, they like gray and light brown and other intermediate colors. We can call this Intermediate colors could be variegated colors. Japanese is always willing to take too much artificial marks to their aesthetic orientation, and ultimately achieve the perfect beauty. For example, Japanese like a cherry which is only blooming about a week, open early and wither, fall early which means they feel its beauty only in that moment. The Japanese are touched by that instant beauty of the momentary ending[2].

\subsection{Game design elements}

We know the 5 graphic elements of the game are as described below : Original painting, game background, character design, sound effects and interface design[4]. Game background design is an important element of the game production, its quality influence the beauty throughout the game. Scene design refers to the space scene in which the subject is, including interior, exterior and props[5]. According to the description of the game plan, we create graphics and its way of thinking to meet the gaming scene, is an integral part of game design. Scene design often includes the work of landscape art department system, and many of the props set.

\section{Comparative analysis}

\subsection{The choice of subjects}

First of all, We collected 25 popular "Three Kingdoms" Games. These 25 games, 9 Korea games, 10 Chinese games, 6 Japanese games. They are:

[Table 1] 25 Stimulus of games

\begin{tabular}{|c|c|c|}
\hline Korea & China & Japan \\
\hline K1. 三國志豪傑傳 & C1. 吞食天地 & J1. 三國志 \\
\hline K2. 莨天 & C2. 三國演義 & J2. 臆姬無雙 \\
\hline K3. 三國殺 & C3. 三國霸業 & J3. 真三國無雙 \\
\hline K4. 三國之星海風雲 & C4. 龍騰三國 & J4. 太閣立志傳 \\
\hline K5. 一騎當千 & C5. 三國群英傳 & J5. 幻想三國志 \\
\hline K6. 千年戰爭 & C6. 三國征戰 & J6. 戰國無雙 \\
\hline K7. 三國之天 & C7. 赤壁 & J7. 武田信玄 \\
\hline \multirow[t]{3}{*}{ K8. 星際三國 } & C8. 名將三國 & \\
\hline & C9. 易三國 & \\
\hline & $\mathrm{C} 10 . \mathrm{QQ}$ 三國 & \\
\hline
\end{tabular}

And let 50 players choose the most representative games. Finally, We choose 6 games as the research objects of this article. And 2 games for each country. Become the research object of this article.

They are: Korean Games: Heaven(蒼天), three days OL (三國之天). China games: Chi bi OL (赤壁)， Three Heroes（三國群英傳）。 Japanese games: Shin Sangokumusou OL 眞.三 國無雙)，Three Kingdoms Series（三國志） 
- A study on the Tendency of Localization for Game Environment Design

- Based on the Analysis in Romance of the Three Kingdoms -

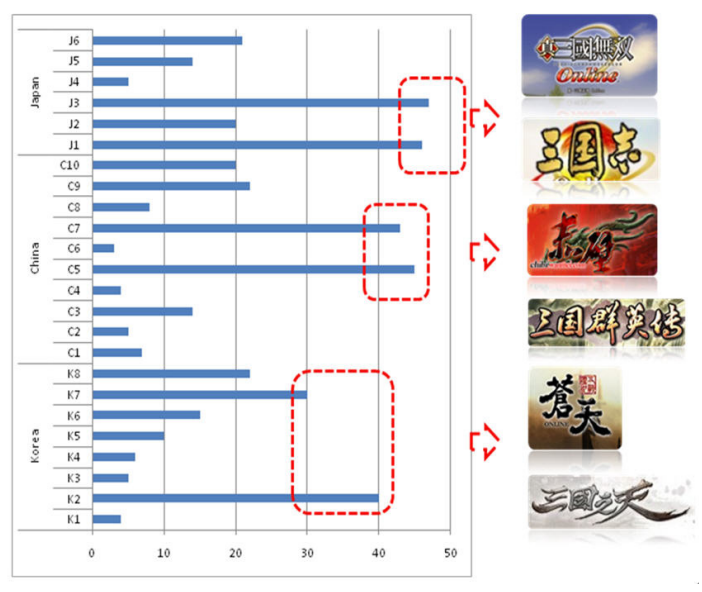

[Fig. 1] Select Results of Stimulus

Then We collected background and Character pictures extensively from these 6 games. Based on several pictures of architecture of the six games, and get 10 students majoring in design to write adjectives. At last, 53 adjectives have been written. 10 other people classified the word category. Using the SPSS (regression analysis), We finally selected 11 key words.

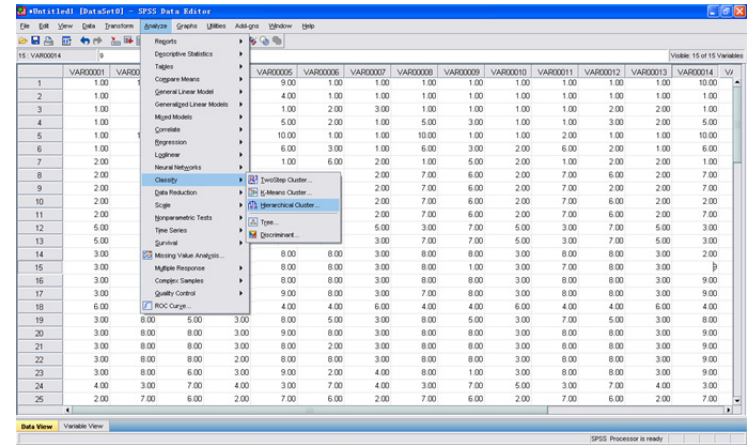

[Fig. 2] Regression analysis with SPSS
Ordering順序的, 8. Chinese nationality 中國民族 感, 9. Gorgeous color 色彩絢麗, 10. Massy 厚 重, 11. Religious 宗敎感

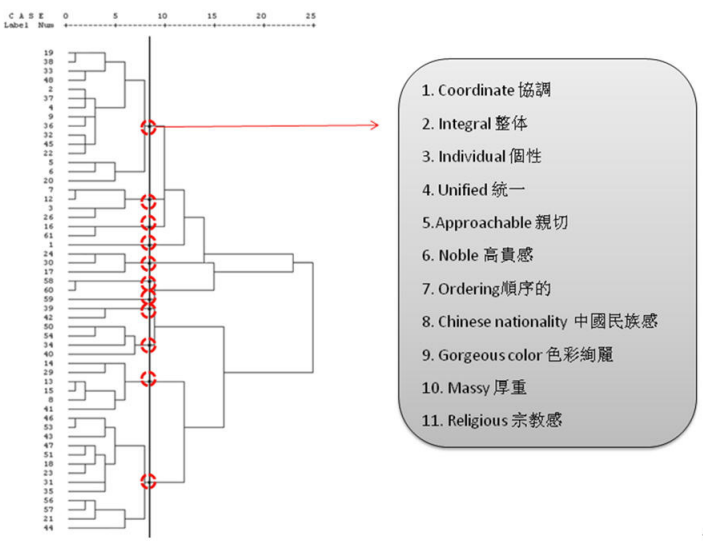

[Fig. 3] Selected key words

\subsection{Game architectural design features}

This investigation goal is the architectural design features in 3 country games. The survey respondents were 50, men: 28, women: 22. Respondents were aged $20-50$ years. 1-7 scale. The arithmetic average analysis of SPSS. 50 players finished the questionnaire survey, and the arithmetic average analysis of SPSS was used. We can see that games of three countries successfully exhibit the style of Chinese traditional game architectural style, follow Chinese traditional culture.

These 11 key words were:

1. Coordinate 協調, 2. Integral 整体, 3. Individual 個性，4. Unified 統一， 5. Approachable 親切, 6. Noble 高貴感， 7 . 


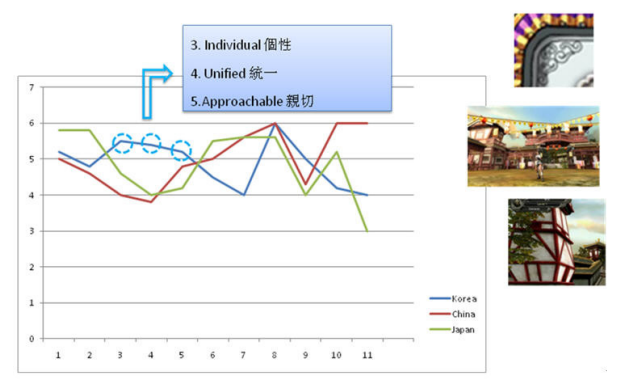

[Fig. 4] Game architectural features of Korean Games

Korean game environment style shows individual, unified, and approachable. It is more randomize and some modern elements were added.

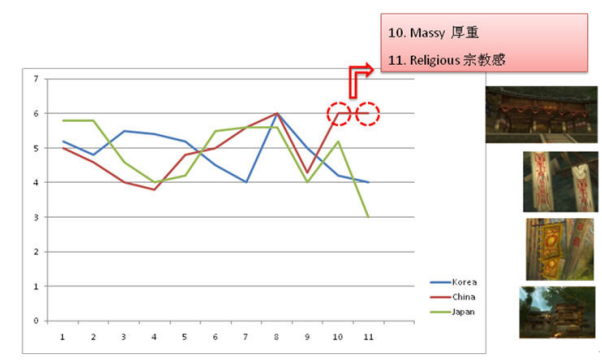

[Fig. 5] Game architectural features of Chinese Games

Chinese game environment style has a strong religious sense and massy sense.

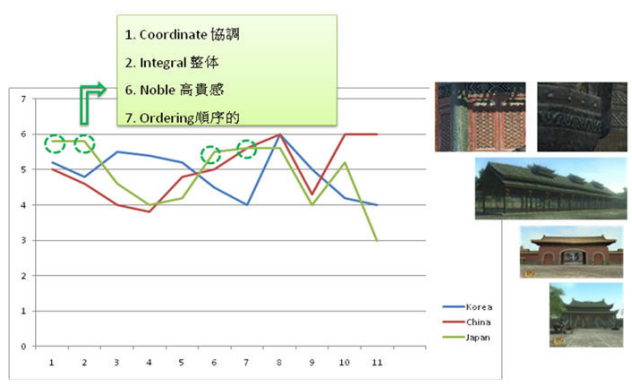

[Fig. 6] Game architectural features of Japanese Games
Japanese game environment style are Coordinate, integral, ordering, is the highest. It is fully following the Chinese game architectural style; its noble sense is strongest.

\subsection{Natural landscapes elements}

First of all, We had collected the visional elements of natural landscapes. Natural landscapes included : topography, bodies of water and plants.

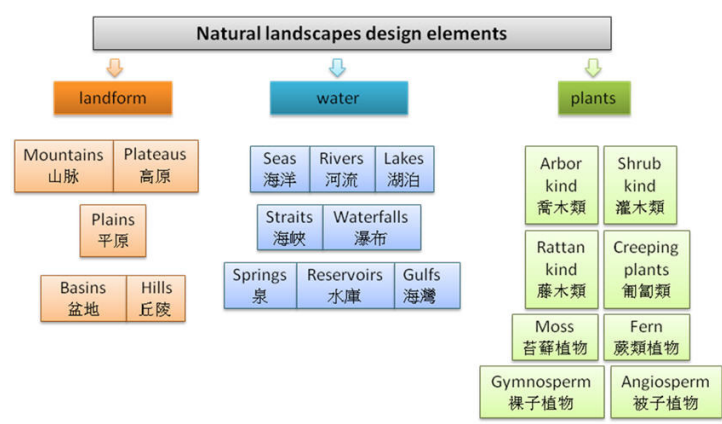

[Fig. 7] Natural landscapes elements

\subsection{Comparative Study}

The research purpose is finding Korean, Chinese and Japanese natural environment design features. Research method is Multiple correspondence analysis. The survey respondents were 30 students, men : 15 students, women : 15 students. Respondents's ages 20-40 years old. More than half the same person answer, it could be effective.

\subsubsection{Landform[6]}

First, We numbered each sample, Korea : 1-20 ordering, China : 21-40 ordering, Japan : 41-60 ordering. 
- A study on the Tendency of Localization for Game Environment Design

- Based on the Analysis in Romance of the Three Kingdoms -

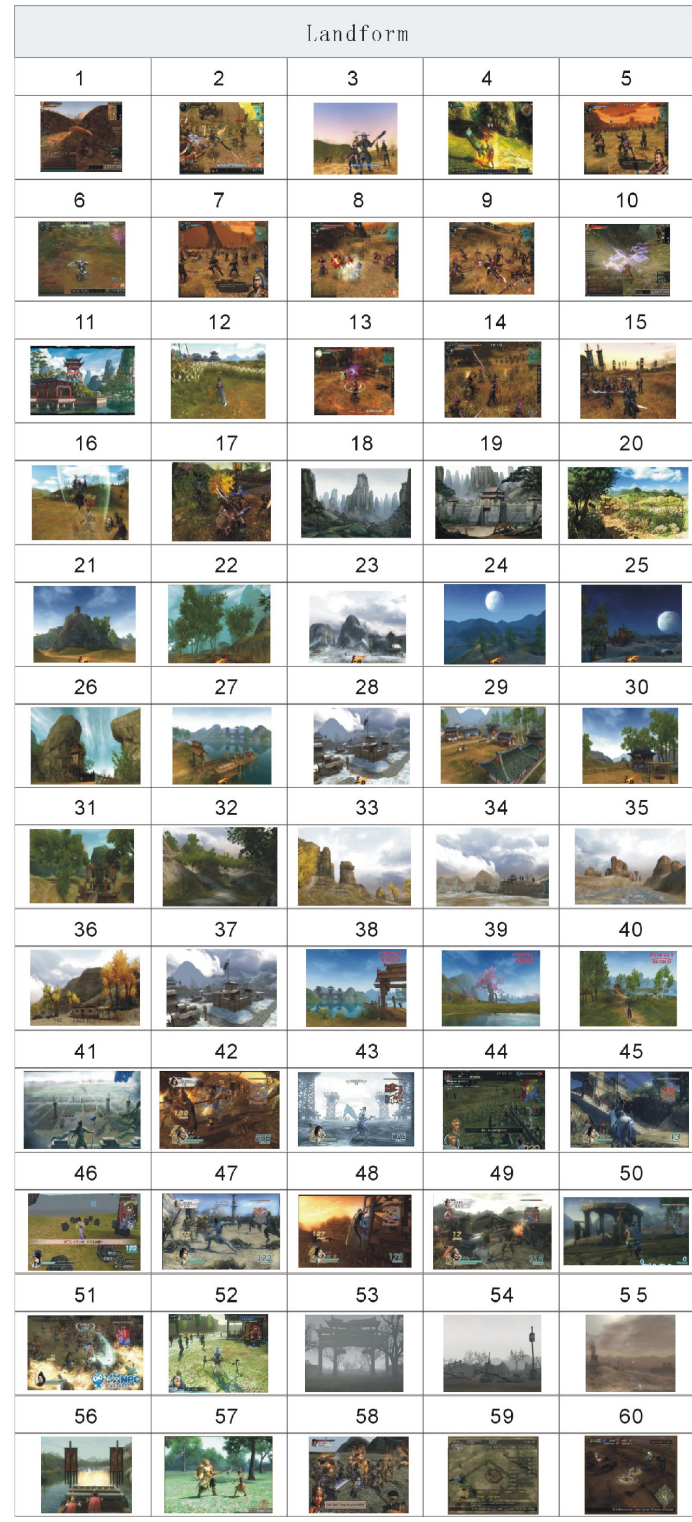

[Fig. 8] The numbering of landform

Combined with design elements, when in-puting data, data with the elements is 2, data without the element is 1 . In excel program, It show the elements are horizontal axis and samples are the vertical axis. Then each group were copied into SPSS data respectively.

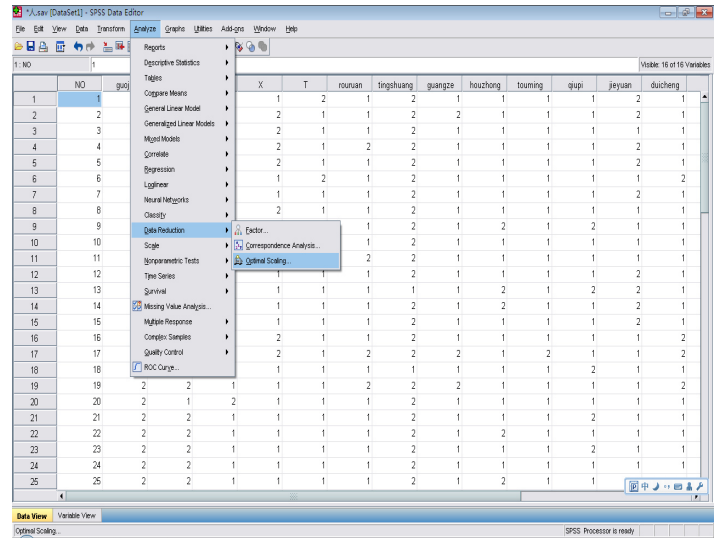

[Fig. 9] Multiple correspondence analysis

Through computing multiple correspondence analysis, the results are as this follows : In first graph, each point represents a sample. And the number is samples number. The distance between points is close to illustrate the more similar. If the distance is farther away, it's indicating greater differences. as combined with the second graph, we can know the sample's meanings.

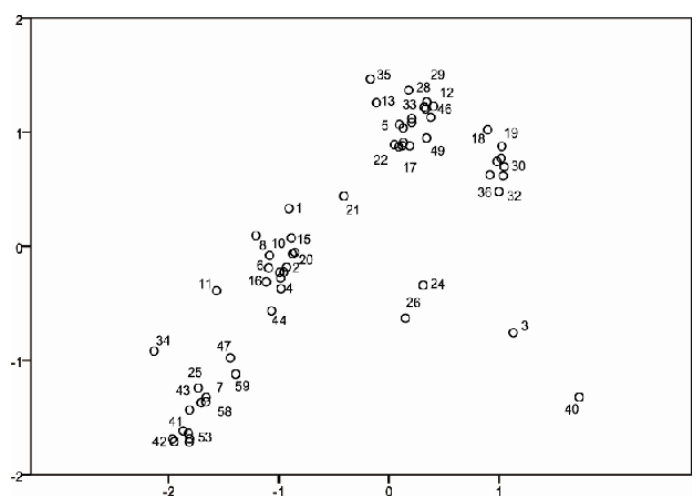




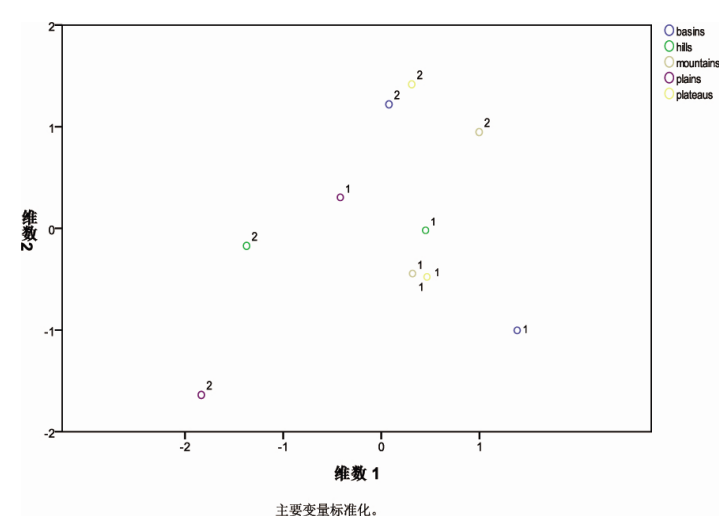

[Fig. 10] Analysis graphs for Landform

In the second graph, each color represents a design element. Number "2" stands for "Yes", it means this element has been used. "1" stands for "no", It means it has not been used.

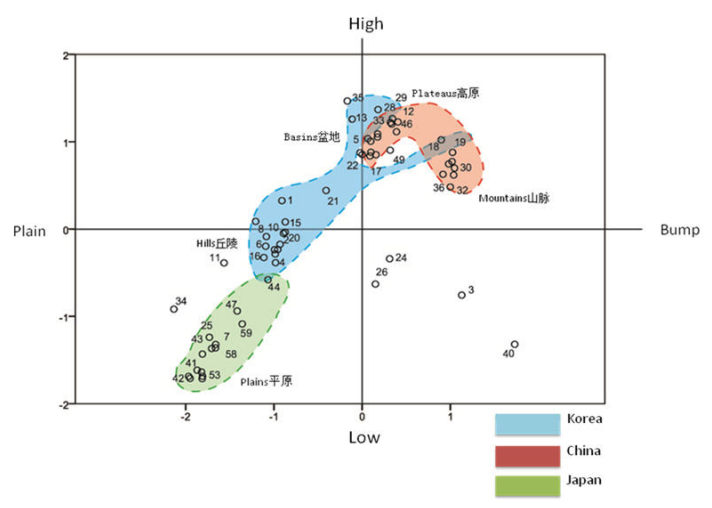

[Fig. 11] Analysis Overlaping graph

As we can see, The landform of korean games are high and plain. The chinese's are high and bump. The japanese's are plain and low. By the percentage of numerical values, we could find out the maximal frequency of the design elements in the three countries, that is, the design characteristics of the three countries.

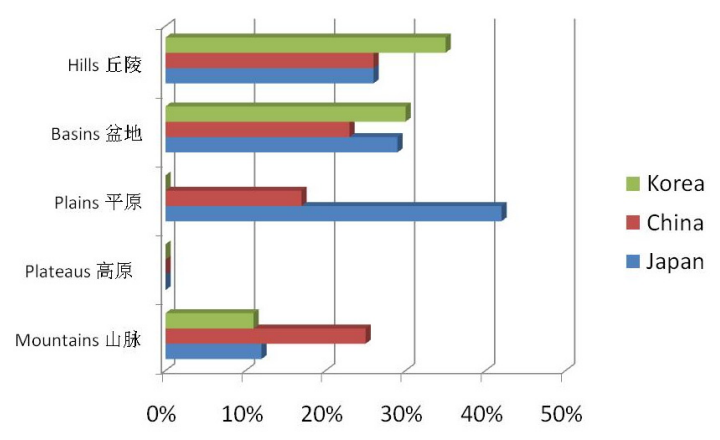

[Fig. 12] Distribution of Landform types

In Korean games, most of landform is basins and hills with a mild gradient. In Chinese game, there are many kinds of landform, most of all it is with high altitude, steep mountains, and plains are less and has broad field of vision. In Japanese games, there are mostly plains with a flat and a small slope

\subsubsection{Water}

First I had numbered each sample (Korea : 1-17 ordering, China : 18-37 ordering, Japan : 38-57 ordering) 
- A study on the Tendency of Localization for Game Environment Design

- Based on the Analysis in Romance of the Three Kingdoms -

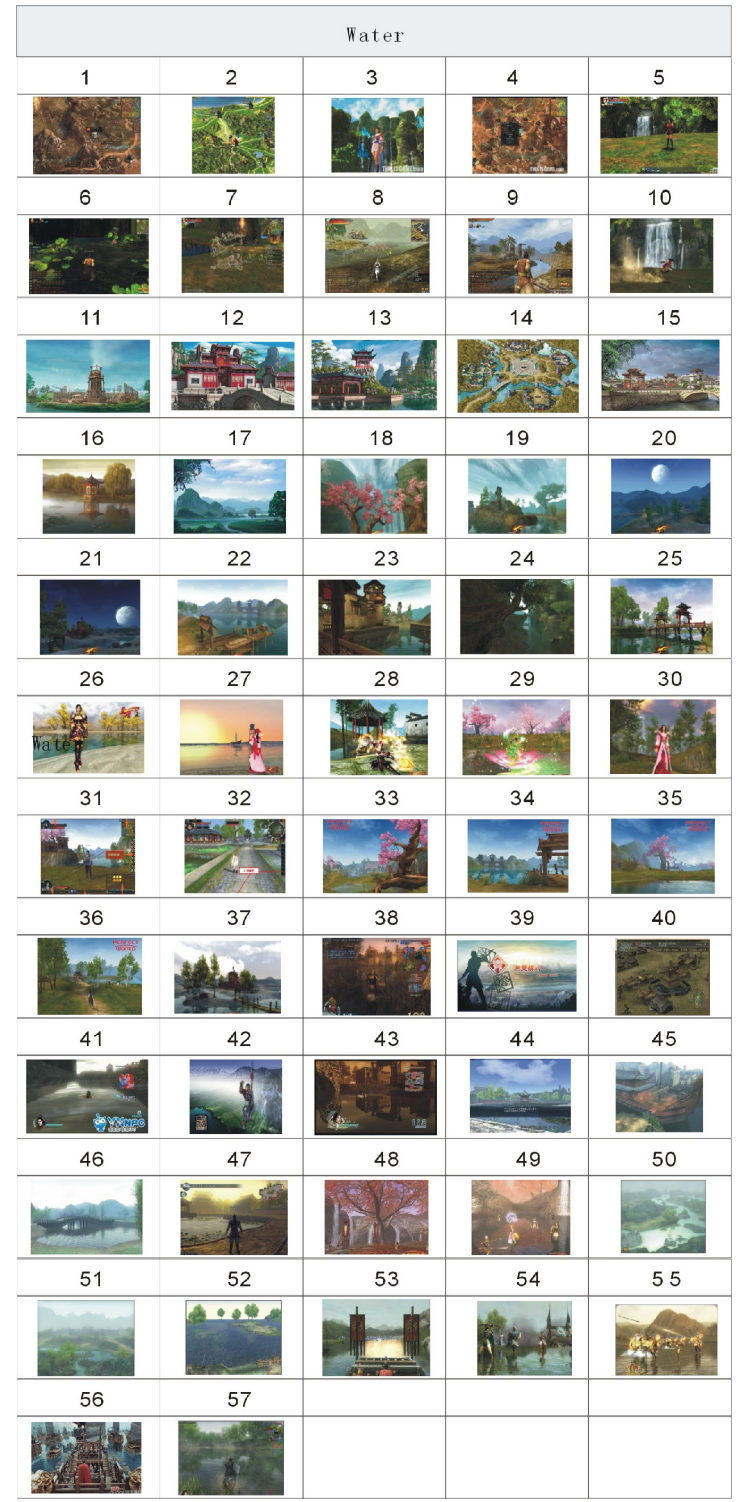

[Fig. 13] The numbering of water

Through combined with design elements, when we were inputing data, with the elements is 2, data without the element is 1 . In excel program, the elements were horizontal axis, samples were the vertical axis. Then each group were copied into SPSS data respectively.

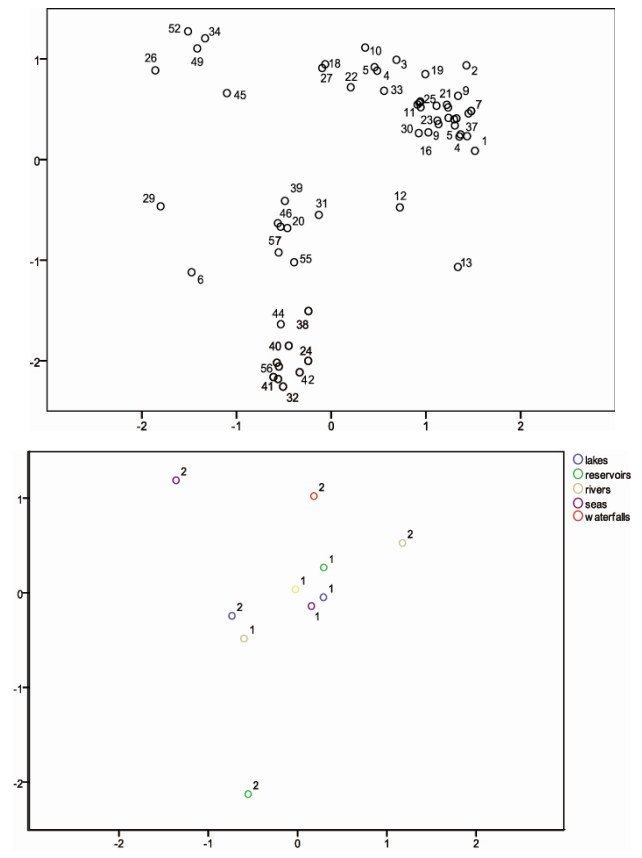

[Fig. 14] Analysis graphs for water

Korean and Chinese game's design of water are same, stream and narrow. Japan game's design of water is wide and static.

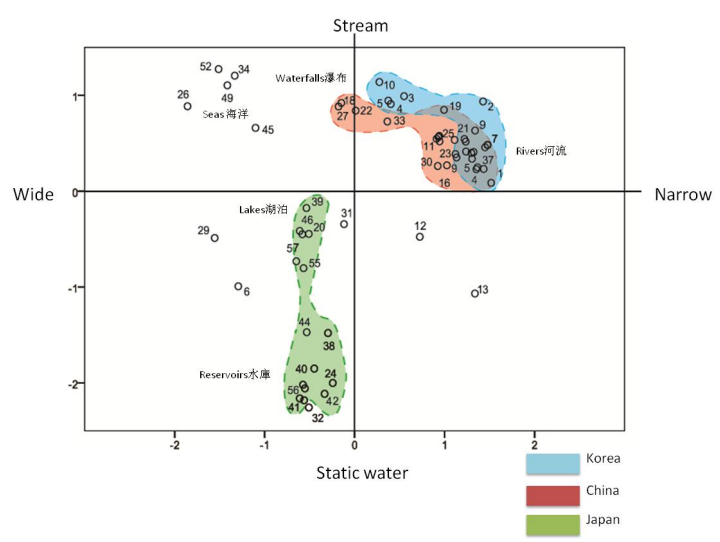

[Fig. 15] Analysis Overlaping graph

Korean and Chinese games use rivers, waterfalls, more streams. In Japan's games, there are main lakes and pools, more, static water. And the trail of artificial is obvious. 


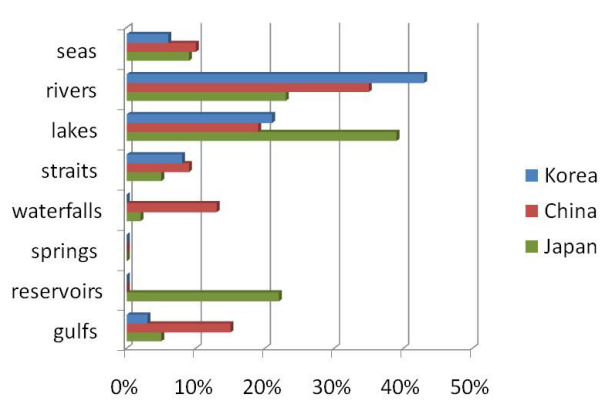

[Fig. 16] Distribution of water types

\subsubsection{Plants}

(Korean : 1-20 ordering, Chinese : 21-40 ordering, Japanese : 41-60 ordering)

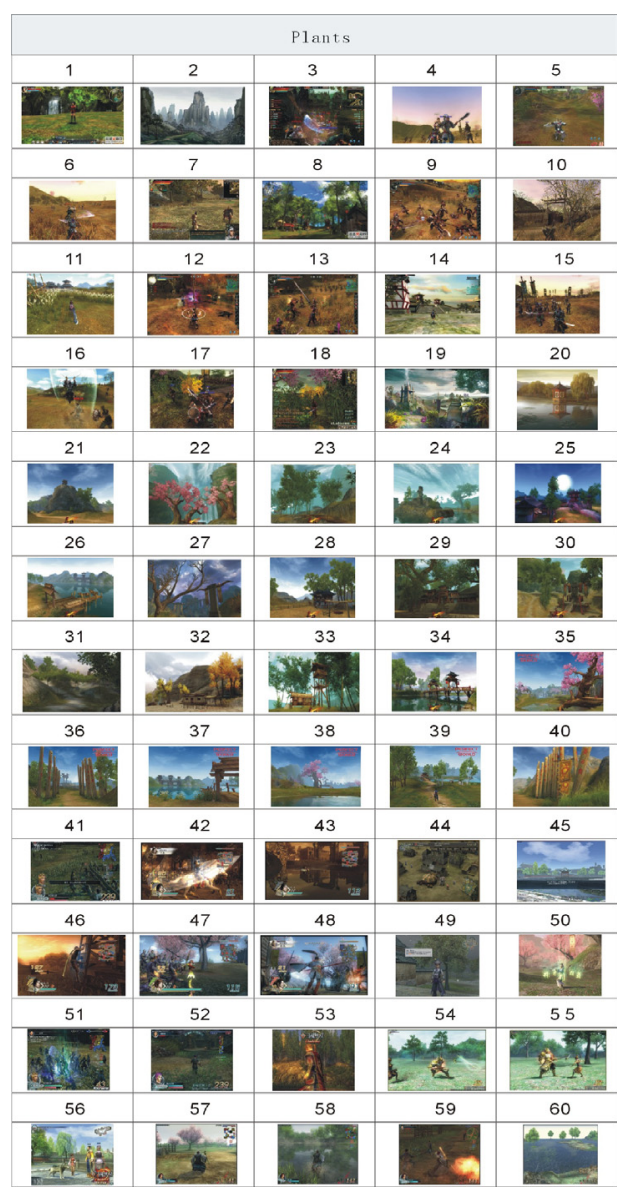

[Fig. 17] The numbering of plants
In excel program, the elements were horizontal axis, samples were the vertical axis. Then each group were copied into SPSS data respectively.

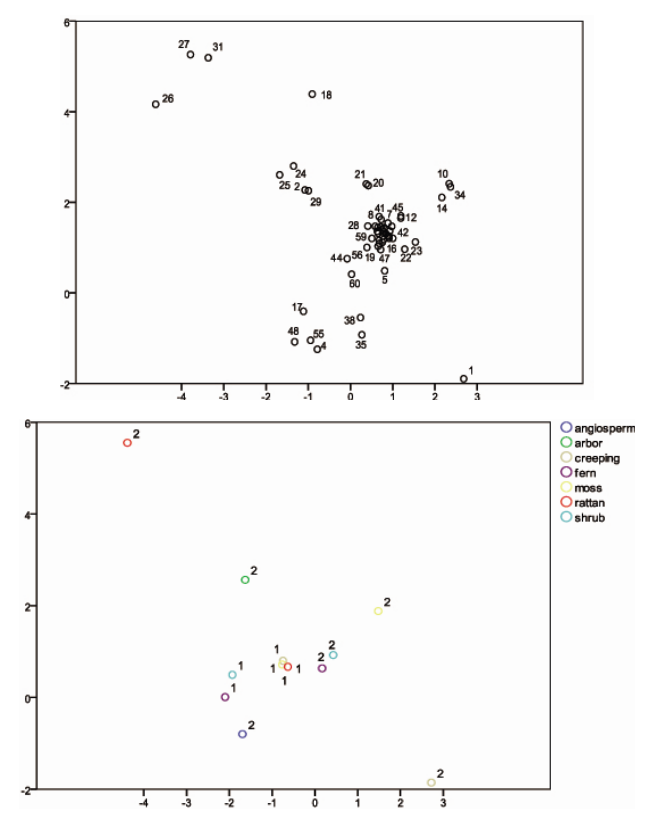

[Fig. 18] Analysis graphs for plants

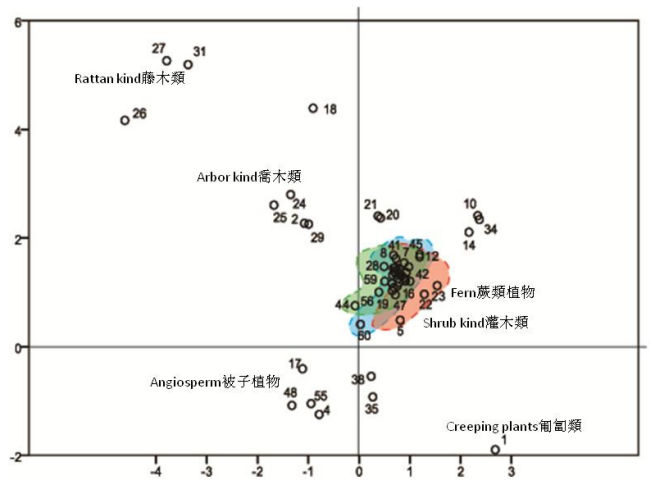

[Fig. 19] Analysis Overlaping graph

The results can be seen like these belows, In three countries' games, they use more short shrubs and grass as the main manifestation of fern. there are nothing to differences. 
- A study on the Tendency of Localization for Game Environment Design

- Based on the Analysis in Romance of the Three Kingdoms -

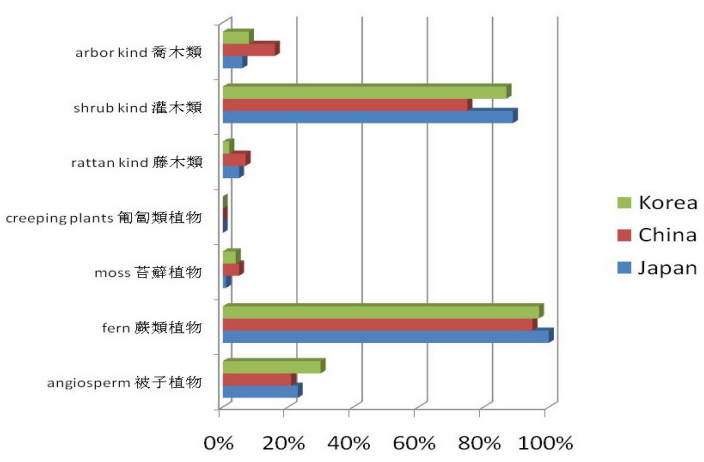

[Fig. 20] Distribution of plants types

\section{Conclusion}

Although the three games are based on the background of the Three Kingdoms and the story plot is similar. Chinese traditional culture has been respected and borrowed in the design. Korean game is incline to a nature, with many hills, rivers and trees, but the most are arranged centralized. Color is very bright. also it gives players a heavy simple, brutal true battlefield and use more metal.

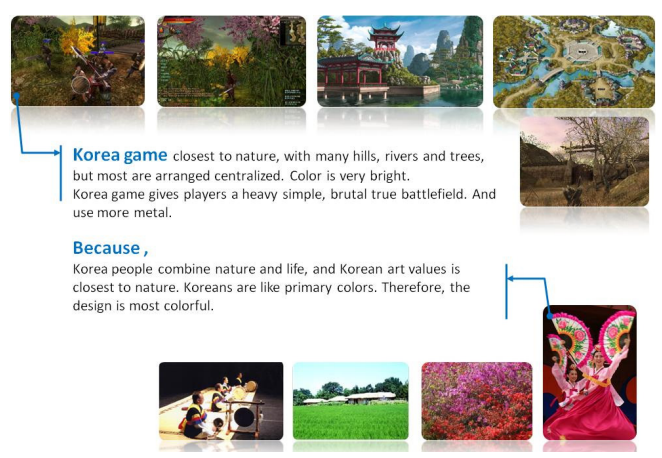

[Fig. 21] Result for Korean games

Korean people likely combine nature and life, and Korean art value is closest to a nature. Koreans like to use primary colors. Therefore, the design is colorful mostly.

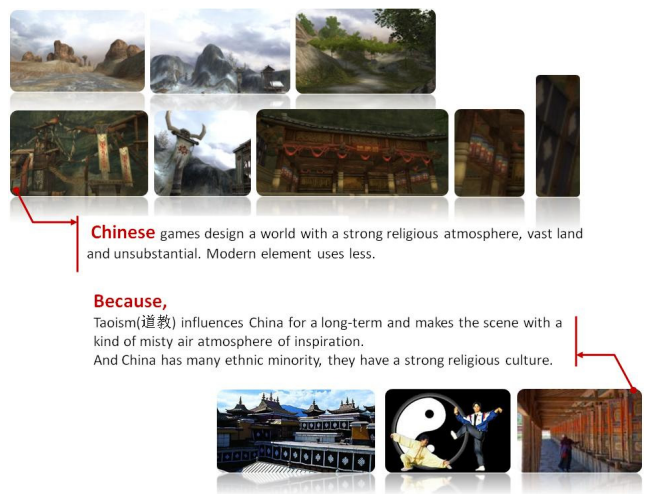

[Fig. 22] Result for Chinese games

Chinese game environment designs have a strong religious atmosphere, vast land and unsubstantial. Modern elements are used less. Because, Taoism(道敎) have a strong influence on China for a long-term and makes the scene with a kind of misty air atmosphere of inspiration. And Chinese has many ethnic minority which has a strong religious culture.

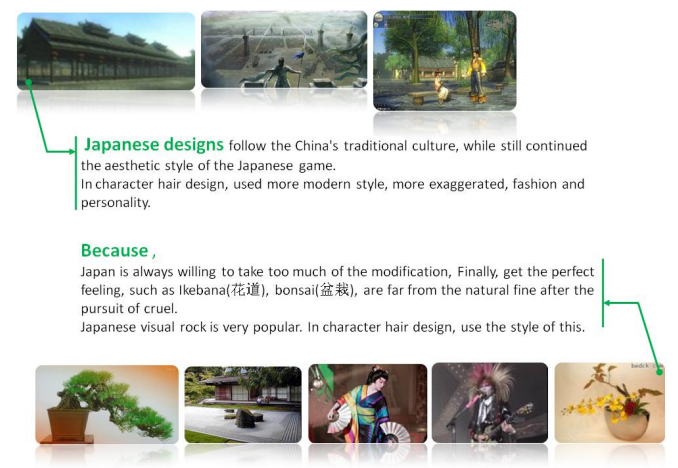

[Fig. 23] Result for Japanese games

Japanese game environment designs follow Chinese traditional culture which means it used more modern style, more exaggerated, fashion and personality. The reason why it is because Japan is always willing to take too much the modification, In other words, it get a 
perfect feeling, such as Ikebana(花道), bonsai (盆栽), are far from the natural fine after the pursuit of cruel. In the development of online games, designers should take the different and various design aesthetics and characteristics of their own countries, insisting on localization designs. "The National One is same as the Global One" - this idea has been recognized rapidly. Games design as well.

\section{REFERENCES}

[1] Jerz, Dennis, "Somewhere Nearby is Colossal Cave: Examining Will Crowther's Original 'Adventure' in Code and in Kentucky”, Digital Humanities Quarterly, 2007.

[2] Jun-Shun Yang, Wen-Chung Wang, "Simple Analysis of the Localization to Design", Light Industry Machinery, Vol. 03 23, 2005.

[3] Dong Jiahao, "The research of online users' participating online game behavior", Taiwan, Huanan University, 2001.

[4] "The investigation and analysis on Chinese online game users", Chinese internet information center, 2008.

[5] "CESA Games White Paper", Computer Entertainment Supplier's Association, 2008.

[6] Kai Qingtang, "Analysis and Research on The Chinese 3D Character Design for Game Animation", A dissertation submitted to tongji University in conformity with the requirements for the degree of Master of Arts, 2007.

[7] Chun-Ji Jin, Kyu-Jung Kim, "A Study on Traditional Art Expression in Chinese Myth Martial MMORPG Character", Journal of Korea Game Society, Vol. 13, No. 2, pp.119 130, 2013.

[8] Yun-Kyung Kim, "A Study on the Current Status and Forecast on Chinese Game in Relation to Game Platform-Focus on SNG", Journal of Korea Game Society, Vol. 10, No. 2, pp.81 88, 2010.

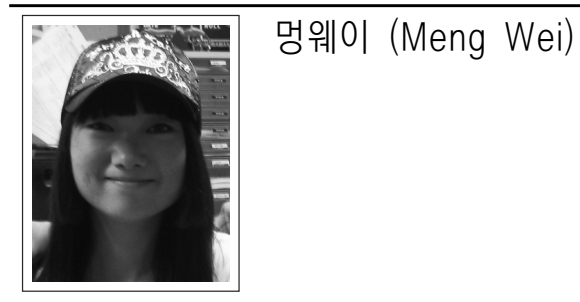

2009. Art College, Chonbuk National University, Korea, Master

관심분야 : Game Character Design

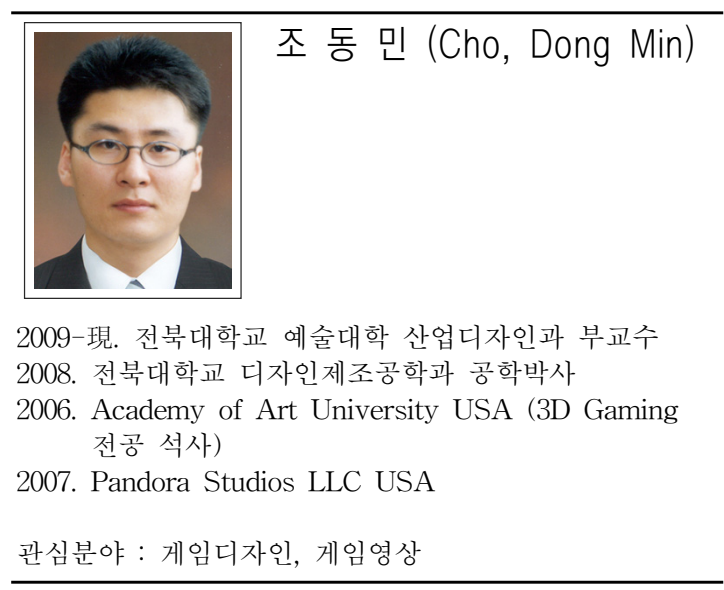


- A study on the Tendency of Localization for Game Environment Design

- Based on the Analysis in Romance of the Three Kingdoms - 